\title{
Effect of Volume Expansion on Renal Citrate and Ammonia Metabolism in KCl-Deficient Rats
}

\author{
Sheldon Adler, Barbara Zett, Barbara Anderson, and \\ Donald S. Fraley \\ From the Department of Medicine, University of Pittsburgh School of Medicine \\ and Montefiore Hospital, Pittsburgh, Pennsylvania 15213
}

A B S T R A C T When rats with desoxycorticosterone acetate (DOCA)-induced potassium chloride deficiency are given sodium chloride there is simultaneously a partial correction of metabolic alkalosis and a marked reduction in urinary citrate excretion and renal citrate content. To examine DOCA's role in this phenomenon and to determine how sodium chloride alters renal metabolism, rats were made $\mathrm{KCl}$ deficient using furosemide and a $\mathrm{KCl}$-deficient diet. Renal citrate and ammonia metabolism were then studied after chronic oral sodium chloride administration or acute volume expansion with isotonic mannitol. Although both maneuvers partially corrected metabolic alkalosis, sodium chloride raised serum chloride concentration while mannitol significantly decreased it. Urinary citrate excretion decreased to $10 \%$ of control in rats given $\mathrm{NaCl}$ and to $50 \%$ of control in rats infused with mannitol. The filtered load of citrate was constant or increased indicating increased tubular citrate reabsorption. Renal cortical citrate content also decreased approximately $50 \%$. Renal cortical slices from $\mathrm{KCl}$-deficient rats incubated in low or normal chloride media produced equal amounts of ${ }^{14} \mathrm{CO}_{2}$ from $\left[1,5-{ }^{14} \mathrm{C}\right]$ citrate. In addition, urinary ammonia excretion increased by over $300 \%$ in both groups. This occurred in the mannitol group despite increased urinary $\mathrm{pH}$ and flow rate indicating a rise in renal ammonia production.

It seems that neither DOCA nor an increase in serum chloride concentration explains the experimental results. Rather, it appears that volume expansion is responsible for increased renal tubular citrate reabsorption and renal ammonia production. As these renal metabolic

This work was previously reported in abstract form: Adler, S., B. Zett, B. Anderson, and D. Fraley. 1974. Role of chloride and volume expansion in regulating renal citrate metabolism. Clin. Res. 22 : 654a.

Received for publication 31 December 1974 and in revised form 14 April 1975. responses ordinarily occur in response to acidosis, the data are consistent with the hypothesis that volume expansion reduces renal cell $\mathrm{pH}$ in $\mathrm{KCl}$-deficient rats.

\section{INTRODUCTION}

Recently, Adler, Zett, and Anderson (1) demonstrated that when desoxycorticosterone acetate (DOCA) ${ }^{1}$-induced chronic potassium chloride-deficient rats are given sodium chloride, but no potassium salts, renal cortical citrate content and urinary citrate excretion profoundly decrease. Renal citrate metabolism was examined because it has been shown that urinary citrate excretion and renal citrate content decrease in acidosis and increase in alkalosis $(2,3)$ presumably secondary to increased renal citrate oxidation in acidosis and a decrease in alkalosis (4). However, Adler and his colleagues noted that despite the enormous reductions in urinary and renal citrate seen after sodium chloride administration, metabolic alkalosis was still present (1). Inasmuch as changes in citrate metabolism in potassium-deficient diaphragm muscle have been shown to be directly related to alterations in intracellular rather than extracellular $\mathrm{pH}$ (5), it was postulated that sodium chloride administration in the potassium chloridedeficient rats may have caused a renal tubular cell acidosis. Unfortunately, direct measurement of renal tubular cell $\mathrm{pH}$ is presently not possible in vivo (6), so this was not able to be confirmed directly.

To test the hypothesis that renal tubular cell $\mathrm{pH}$ is lowered by sodium chloride ingestion in potassium chloride deficiency and to determine the mechanism through which sodium chloride induces changes in renal citrate metabolism, further experiments were performed. To eliminate the possible role of exogenously

\footnotetext{
${ }^{1}$ Abbreviation used in this paper: DOCA, desoxycorticosterone acetate.
} 
administered DOCA, rats were made potassium chloride deficient by intraperitoneal furosemide administration. The roles played by extracellular chloride concentration and volume expansion in altering renal cell $\mathrm{pH}$ were studied by examining their effects on renal citrate and ammonia metabolism. The results indicate that the response of renal citrate metabolism to sodium chloride ingestion in the furosemide-induced potassium chloridedeficient rats was identical to the response of renal citrate metabolism to sodium chloride ingestion in rats made deficient with DOCA. In addition to the changes in renal citrate metabolism, sodium chloride or mannitol induced volume expansion increased ammonia excretion. These renal metabolic alterations appear to be due to an expansion of intravascular volume rather than a change in plasma chloride concentration. The data are consistent with the hypothesis that expansion of intravascular volume in potassium chloride-deficient rats leads to a decrease in renal tubular cell $\mathrm{pH}$.

\section{METHODS}

Potassium chloride depletion protocol. Male SpragueDawley rats weighing $350-375 \mathrm{~g}$ were used in all experiments. Each animal was placed on a zero potassium, zero chloride diet (obtained from Nutritional Biochemical Corporation, Cleveland, Ohio). Animals were allowed water containing $75 \mathrm{meq} /$ liter of sodium bicarbonate ad libitum during the entire study. Rats were maintained on the potassium chloride-deficient diet for a 15-day period. On days 8-12 each rat received a daily intraperitoneal dose of $2 \mathrm{mg}$ of furosemide.

Repletion protocol. At the end of the 15-day period all food was removed, and the rats were divided into four equal groups: a $\mathrm{KCl}$-repleted group tube fed $10 \mathrm{ml}$ of a $20 \%$ dextrose solution containing $200 \mathrm{meq} /$ liter $\mathrm{KCl}$ twice daily; a K-depleted group tube fed $10 \mathrm{ml}$ of $20 \%$ dextrose solution containing no electrolytes twice daily; an $\mathrm{NaCl}-$ repleted group tube fed $10 \mathrm{ml}$ of a $20 \%$ dextrose solution containing $200 \mathrm{meq} /$ liter sodium chloride twice daily; and a KHCOr-repleted group tube fed $10 \mathrm{ml}$ of a $20 \%$ dextrose solution containing $200 \mathrm{meq} / \mathrm{liter} \mathrm{KHCO}_{\mathrm{s}}$ twice daily. Solutions were administered for 3 days during which the sodium bicarbonate drinking water was continued ad libitum. Rats were weighed each morning during this 3-day repletion. After 3 days of tube feeding rats were sacrificed the next day as outlined below.

Citrate and ammonia excretion experiments in repleted rats. After receiving the sixth tube feeding each rat was placed in an individual metabolic cage and given only the sodium bicarbonate solution ad libitum. Urine was collected for the next $16 \mathrm{~h}$. At the end of this time rats were removed from the cages which were then rinsed with distilled water to insure complete urine collection. Each urine collection was filtered and analyzed for creatinine, chloride, citrate, and ammonia.

Tissue electrolyte and citrate experiments in repleted rats. Animals were anesthetized by the intraperitoneal injection of inactin, $100 \mathrm{mg} / \mathrm{kg}$ of body weight. Each rat was anesthetized separately to avoid any delay before killing the rat by exsanguination from the abdominal aorta into a heparinized syringe. Portions of renal cortical tissue, liver, and gluteal muscle were removed and rapidly frozen in liquid nitrogen for citrate analysis. Other portions of these tissues were placed in tared tubes for later determination of water and potassium content. All the frozen tissues were weighed and homogenized in the frozen state. The homogenate was centrifuged and the supernate saved for citrate analysis.

${ }^{14} \mathrm{CO}$, production from $\left[1,5-{ }^{14} \mathrm{C}\right]$ citrate experiments. As previously described (2) renal cortical slices were placed into specially constructed $25-\mathrm{ml}$ Erlenmeyer flasks having a center well. Approximately $100 \mathrm{mg}$ of renal cortex was used in each flask. Each flask contained $4 \mathrm{ml}$ of a carbon dioxide-oxygen saturated Krebs-Ringer bicarbonate solution containing $1.0 \mathrm{meq} / \mathrm{liter}$ of potassium. The substrate was 1 $\mathrm{mM}$ acetate and $1 \mathrm{mM}$ citrate. In addition, each flask contained $0.5 \mu \mathrm{Ci}$ of $\left[1,5-{ }^{14} \mathrm{C}\right]$ citrate (obtained from New England Nuclear, Boston, Mass.). The solution in one group of flasks contained $70 \mathrm{meq}$ of sodium chloride, while the solution in the other group contained $110 \mathrm{meq}$ of sodium chloride. Isoosmolarity was achieved by the addition of mannitol to the first flask. Flasks were incubated for 90 min in a metabolic shaker at $37^{\circ} \mathrm{C}$, and ${ }^{14} \mathrm{CO}_{2}$ was collected and counted as previously described (2). Results are expressed as disintegrations per minute per flask per $200 \mathrm{mg}$. Calculations of this value have also been previously described (2). Production of ${ }^{14} \mathrm{CO}_{2}$ from labeled citrate in the remainder of the paper will be termed citrate decarboxylation.

Mannitol expansion experiments. Potassium chloride-depleted rats were employed in all experiments. After the 15-day depletion protocol the potassium chloride-depleted rats were anesthetized by the intraperitoneal injection of inactin, $100 \mathrm{mg} / \mathrm{kg}$ of body weight. A tracheostomy was performed in each animal to allow for removal of retained secretions. An indwelling jugular catheter was inserted for infusion, and a femoral artery line was placed for blood sampling. The infusion line was connected to a Harvard constant infusion pump (Harvard Apparatus Co., Inc., Millis, Mass.). A bladder catheter was inserted suprapubically. After a 30-min stabilization period, animals were divided into two groups. The dextrose-infused group received $8.3 \mathrm{ml} / \mathrm{h}$ of a $5 \%$ dextrose solution over a $210-\mathrm{min}$ period. The mannitol-infused group was given $8.3 \mathrm{ml} / \mathrm{h}$ of the $5 \%$ dextrose solution for $90 \mathrm{~min}$ to act as a control period. These animals were then infused with a $280 \mathrm{mM}$ mannitol solution given at $37 \mathrm{ml} / \mathrm{min}$ for $150 \mathrm{~min}$. In the dextrose group blood was obtained after the stabilization period and at the conclusion of the experiment. In the mannitol-infused group blood was obtained at the end of the stabilization period, at the end of the control period, and at the conclusion of the experimental period. Urine collected under oil in the dextrose-infused group was obtained as a single sample over the entire $210 \mathrm{~min}$. In the mannitolinfused rats a 90-min control period urine was obtained, and $30 \mathrm{~min}$ after mannitol infusion was started a $60-\mathrm{min}$ and two 30-min urines were collected under oil. Urines in both groups were analyzed for $\mathrm{pH}$, creatinine, citrate, and ammonia. Each group was infused with radioisotopes immediately after the stabilization period. Dextrose-infused rats received $2 \mu \mathrm{Ci}$ each of $\mathrm{Na}{ }^{86} \mathrm{Cl}$ and $\left[{ }^{14} \mathrm{C}\right] \mathrm{DMO}$ and 10 $\mu \mathrm{Ci}$ of tritiated water. Double this quantity was given to the mannitol-infused group to compensate for increased urinary losses. Isotopes were injected early to allow sufficient tissue equilibration time to take place. At the conclusion of the experiment animals in each group were killed by exsanguination from the abdominal aorta into a heparinized syringe. Portions of renal cortical tissue were removed and immediately frozen in liquid nitrogen, weighed, homogenized in a frozen state, and saved for citrate analysis as previously 
TABLE I

Arterial Acid-Base Status and Arterial and Tissue Potassium Levels in Potassium Chloride-Repleted, Potassium-Depleted, Sodium Chloride-Repleted, and Potassium Bicarbonate-Repleted Rats*

\begin{tabular}{|c|c|c|c|c|c|c|}
\hline & \multicolumn{4}{|c|}{ Blood } & \multicolumn{2}{|c|}{ Tissue potassium } \\
\hline & $\mathrm{pH}$ & $\mathrm{HCO}_{2}$ & $\mathrm{PCo}_{2}$ & $\mathbf{K}$ & Muscle & Kidney \\
\hline & & meq/liter & $m m \mathrm{Hg}$ & meq/liter & \multicolumn{2}{|c|}{ meq/kg dry weight } \\
\hline $\mathrm{KCl}$ repleted, $n=5$ & $\begin{array}{r}7.42 \ddagger \\
\pm 0.01\end{array}$ & $\begin{array}{l}20.8 \ddagger \\
\pm 1.7\end{array}$ & $\begin{array}{l}32 \ddagger \\
\pm 3\end{array}$ & $\begin{array}{l}3.9 \ddagger \\
\pm 0.2\end{array}$ & $\begin{array}{l}471 \ddagger \\
\pm 9\end{array}$ & $\begin{array}{r}339 \\
\pm 14\end{array}$ \\
\hline $\mathrm{K}$ depleted, $n=7$ & $\begin{aligned} & 7.55 \S \\
\pm & 0.02\end{aligned}$ & $\begin{array}{l}36.48 \\
\pm 1.8\end{array}$ & $\begin{array}{l}41 \S \\
\pm 1\end{array}$ & $\begin{array}{l}2.3 \S \\
\pm 0.2\end{array}$ & $\begin{array}{l}357 \S \\
\pm 9\end{array}$ & $\begin{array}{l}319 \\
\pm 9\end{array}$ \\
\hline $\mathrm{NaCl}$ repleted, $n=7$ & $\begin{array}{r}7.48 \\
\pm 0.03\end{array}$ & $\begin{array}{l}26.0 \pm \S \\
\pm 1.2\end{array}$ & $\begin{array}{l}35 \ddagger \\
\pm 2\end{array}$ & $\begin{aligned} & 2.6 \S \\
\pm & 0.1\end{aligned}$ & $\begin{array}{l}365 \S \\
\pm 10\end{array}$ & $\begin{array}{l}318 \\
\pm 5\end{array}$ \\
\hline $\mathrm{KHCO}_{3}$ repleted, $n=6$ & $\begin{aligned} & 7.55 \S \\
\pm & 0.01\end{aligned}$ & $\begin{array}{c}32.78 \\
\pm 1.0\end{array}$ & $\begin{array}{l}38 \S \\
\pm 1\end{array}$ & $\begin{aligned} & 2.4 \S \\
\pm & 0.2\end{aligned}$ & $\begin{array}{l}348 \S \\
\pm 12\end{array}$ & $\begin{array}{l}328 \\
\pm 6\end{array}$ \\
\hline
\end{tabular}

* Values represent the mean $\pm \mathrm{SE}$ of the mean.

$¥$ Differ from $\mathrm{K}$ deplete $P<0.01$, using Student $t$ test.

$\$$ Differ from $\mathrm{KCl}$ replete $P<0.01$, using Student $t$ test.

described (2). A portion of renal cortex, plus liver, gluteal muscle, and cardiac muscle tissue were placed in tared tubes for later determination of water and potassium content. A portion of gluteal muscle, cardiac muscle, and liver tissue was placed in weighed homogenizing tubes for determination of intracellular $\mathrm{pH}$, as previously described (7).

Analytic methods. Blood $\mathrm{pH}$ and $\mathrm{PCO}_{2}$ were measured on a Radiometer BM3 MK2 blood micro system at $37^{\circ} \mathrm{C}$. Urine $\mathrm{pH}$ was measured using a Radiometer PMS27 $\mathrm{pH}$ meter. Bicarbonate concentration in the blood was calculated from the Henderson-Hasselbalch equation employing a $\mathrm{pK}$ of 6.1. Sodium and potassium were measured on an IL flame photometer while chloride, creatinine, and blood urea nitrogen (BUN) were determined by autoanalyzer. Tissue water and electrolytes were determined by drying tissue to constant weight in a $70^{\circ} \mathrm{C}$ oven for $16 \mathrm{~h}$, as previously described (2). Citrate was determined enzymatically (8), and ammonia was determined by microdiffusion (9). Triple isotope determination of tissue $\mathrm{pH}$ employed the methods described by Schloerb and Grantham (10). Radioactivity was measured in a three channel Packard liquid scintillation counter (Packard Instrument Co., Inc., Downers Grove, IIl.) using a AES standardization and standard methods for determining efficiencies.

\section{RESULTS}

Effect of sodium chloride repletion on renal citrate metabolism and urinary ammonia excretion in $\mathrm{KCl}$ depleted rats. Extracellular acid-base status and serum and tissue potassium levels in the four groups of rats studied are shown in Table I. With the exception of the potassium chloride-repleted rats, metabolic alkalosis was present in each group. Compared to potassiumdepleted and potassium bicarbonate-repleted animals, however, the severity of the metabolic alkalosis was less in the sodium chloride-repleted rats, $P<0.05$. Thus, sodium chloride partially corrected the alkalosis, a result previously shown by other investigators in DOCA-induced potassium-deficient animals $(1,11)$. The furosemide and dietary $\mathrm{KCl}$ restriction regimen induced a state of severe potassium depletion. Muscle potassium concentration was reduced $25 \%$ in each of the last three groups compared to values found both in the potassium chloride-repleted animals and normal values obtained in this and other laboratories $(P<$ 0.001 ). Renal potassium concentration was also reduced but the degree of reduction, as expected, was less than in the muscle (1). It is important to note that despite administration of potassium bicarbonate serum and muscle potassium depletion was as severe as that found in sodium chloride and potassium-depleted animals who received no potassium. Administration of potassium bicarbonate, unlike potassium chloride, was unable to restore extracellular acid-base conditions, serum potassium concentration, or tissue potassium concentration to normal. The efficacy of sodium chloride administration in repleting chloride stores is shown both by the rise in serum chloride concentration from 80 to 94 meq/liter and by the large amounts of chloride in the urine of the $\mathrm{NaCl}$-repleted rats (Table II).

In addition to partially correcting the extracellular metabolic alkalosis, administration of sodium chloride also altered renal metabolism. As shown in Fig. 1 and 2 urinary citrate excretion fell while urinary ammonia excretion rose in the sodium chloride-repleted rats. Citrate excretion in the sodium chloride-repleted group, compared to each of the three other groups, differed significantly $(P<0.001)$ as did ammonia excretion $\left(P<0.001\right.$ vs. $\mathrm{K}$ depleted and $\mathrm{KHCO}_{3}$ and $P<0.02$ compared to $\mathrm{KCl}$-repleted animals). The alteration in 
TABLE II

Arterial Blood Concentrations of Urea, Creatinine and Citrate, Urinary Chloride Excretion, and Renal Cortical Citrate Content in the Four Groups of Rats*

\begin{tabular}{|c|c|c|c|c|c|}
\hline & \multicolumn{3}{|c|}{ Blood } & \multirow{2}{*}{$\begin{array}{l}\text { Urinary } \\
\text { chloride } \\
\text { excretion }\end{array}$} & \multirow[b]{2}{*}{$\begin{array}{l}\text { Renal cortical } \\
\text { citrate content }\end{array}$} \\
\hline & $\begin{array}{c}\text { Urea } \\
\text { nitrogen }\end{array}$ & Creatinine & Citrate & & \\
\hline & $\mathrm{g} / 100 \mathrm{ml}$ & $\mathrm{g} / 100 \mathrm{ml}$ & $\mu m o l / m l$ & meq/liter & $\mu \mathrm{mol} / \mathrm{g}$ wet weight \\
\hline $\mathrm{KCl}$ replete, $n=5$ & $\begin{array}{l}11.2 \ddagger \\
\pm 0.6\end{array}$ & $\begin{array}{r}0.48 \\
\pm 0.04\end{array}$ & $\begin{array}{r}0.059 \\
\pm 0.005\end{array}$ & $\begin{array}{l}121 \ddagger \\
\pm 25\end{array}$ & $\begin{array}{r}0.346 \\
\pm 0.060\end{array}$ \\
\hline K deplete, $n=7$ & $\begin{array}{l}20.7 \S \\
\pm 2.4\end{array}$ & $\begin{array}{r}0.50 \\
\pm 0.04\end{array}$ & $\begin{array}{c}0.57 \\
\pm 0.006\end{array}$ & $\begin{aligned} & 3.4 \S \\
\pm & 0.5\end{aligned}$ & $\begin{array}{r}0.316 \\
\pm 0.046\end{array}$ \\
\hline $\mathrm{NaCl}$ replete, $n=7$ & $\begin{array}{l}12.0 \ddagger \\
\pm 1.2\end{array}$ & $\begin{array}{r}0.46 \\
\pm 0.02\end{array}$ & $\begin{array}{r}0.060 \\
\pm 0.008\end{array}$ & $\begin{array}{l}147 \S \\
\pm 28\end{array}$ & $\begin{aligned} & 0.1581 \S \\
\pm & 0.025\end{aligned}$ \\
\hline $\mathrm{KHCO}_{3}$ replete, $n=6$ & $\begin{array}{r}14.2 \\
\pm 2.0\end{array}$ & $\begin{array}{r}0.52 \\
\pm 0.02\end{array}$ & $\begin{aligned} & 0.090 \pm \S \\
\pm & 0.008\end{aligned}$ & $\begin{array}{r}4.2 \ddagger \\
\pm 0.8\end{array}$ & $\begin{aligned} & 0.819 \ddagger \S \\
\pm & 0.075\end{aligned}$ \\
\hline
\end{tabular}

* Values represent the mean $\pm \mathrm{SE}$ of the mean.

$\ddagger$ Differ from deplete $P<0.01$, using Student $t$ test.

$\S$ Differ from $\mathrm{KCl}$ replete $P<0.01$, using Student $t$ test.

citrate excretion in $\mathrm{NaCl}$-repleted rats apparently was not secondary to changes in the filtered load of citrate. Table II shows that serum creatinine levels were not significantly different between groups, and only in the potassium-depleted group was BUN elevated $(P<$ 0.01 ), indicating equal glomerular filtration rates in the several groups. Blood citrate levels were elevated only in the potassium bicarbonate rats so filtered citrate in each of the first three groups studied probably was the same. Increased citrate excretion in the $\mathrm{KHCO}_{3}$

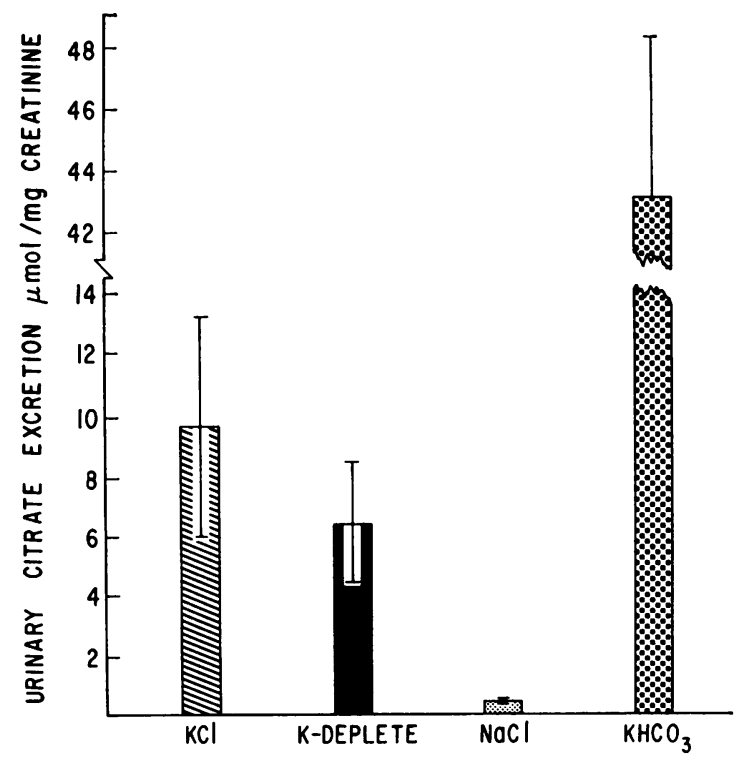

FIgURE 1 Urinary citrate excretion in the four groups of repleted rats. The brackets represent $\pm 1 \mathrm{SE}$ of the mean. group is easily accounted for by the elevated filtered load. Evidence that the observed change in renal citrate metabolism in the $\mathrm{NaCl}$-repleted rats was not due to filtered load is presented in the last column of Table II. The data show that in addition to the reduced citrate excretion, renal cortical citrate content also decreased significantly in the sodium chloride-repleted animals ( $P<0.001$ vs. each of the three other groups). Sodium chloride given to $\mathrm{KCl}$-deficient rats, therefore, induces changes in both renal citrate and ammonia metabolism.

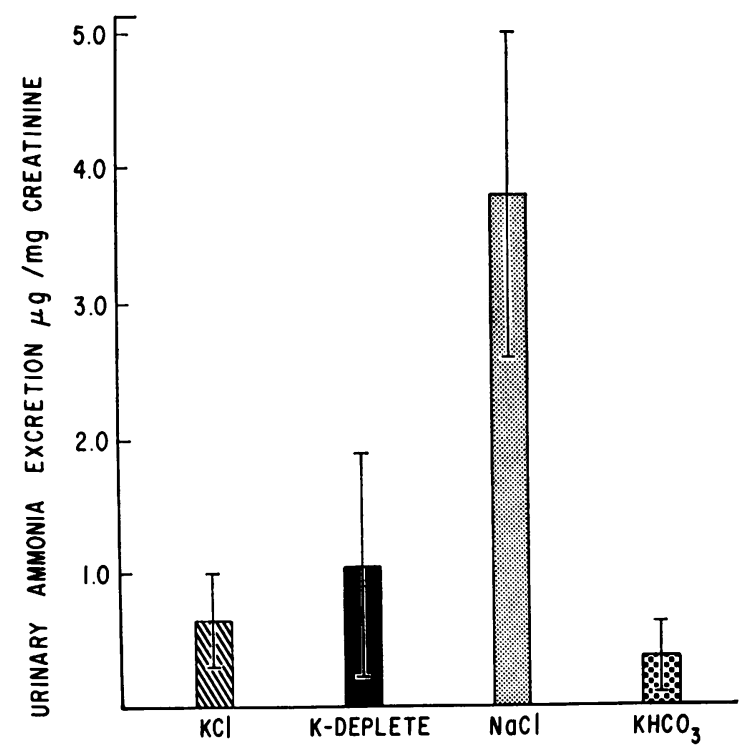

FIGURE 2 Urinary ammonia excretion in the four groups of repleted rats. The brackets represent $\pm 1 \mathrm{SE}$ of the mean. 
TABLE III

Arterial Blood Values in KCi-Depleted Rats Infused with either Dextrose or Mannitol Solutions*

\begin{tabular}{|c|c|c|c|c|c|c|c|c|}
\hline & $\mathrm{pH}$ & $\mathrm{PCO}_{2}$ & $\mathrm{HCO}_{3}$ & $\mathrm{Na}$ & $\mathrm{Cl}$ & $\mathrm{K}$ & Creatinine & Citrate \\
\hline & & $m m \mathrm{Hg}$ & $m e q / l i$ & & & & $\mathrm{~g} / 100 \mathrm{ml}$ & $\mu \mathrm{mol} / \mathrm{ml}$ \\
\hline \multicolumn{9}{|c|}{ Dextrose infused, $n=12$} \\
\hline \multirow[t]{2}{*}{ Initial } & 7.50 & 46 & 36.3 & - & - & - & - & - \\
\hline & \pm 0.02 & \pm 3 & \pm 1.8 & & & & & \\
\hline \multirow[t]{2}{*}{ Final } & 7.49 & 46 & 35.1 & 134 & 79 & 2.4 & 0.56 & 0.073 \\
\hline & \pm 0.02 & \pm 3 & \pm 1.6 & \pm 2 & \pm 2 & \pm 0.1 & \pm 0.06 & \pm 0.007 \\
\hline \multicolumn{9}{|c|}{ Mannitol infused, $n=13$} \\
\hline \multirow[t]{2}{*}{ Initial } & 7.47 & 52 & 37.3 & 140 & - & 2.4 & - & - \\
\hline & \pm 0.02 & \pm 3 & \pm 1.0 & \pm 4 & & \pm 0.1 & & \\
\hline \multirow[t]{2}{*}{ Final } & 7.46 & $45 \ddagger$ & $31.8+\S$ & $113+\S$ & $<70 \S$ & 2.6 & 0.57 & 0.080 \\
\hline & \pm 0.01 & \pm 2 & \pm 1.3 & \pm 3 & & \pm 0.2 & \pm 0.06 & \pm 0.004 \\
\hline
\end{tabular}

* Values represent the mean $\pm \mathrm{SE}$ of the mean.

$\ddagger$ Value differs significantly from initial value $(P<0.05)$.

$\S$ Difference from final dextrose infused value statistically significant $(P<0.01)$.

In an attempt to delineate the mechanism involved, further experiments were performed.

${ }^{14} \mathrm{CO}$ s production from $\left[1,5-{ }^{14} \mathrm{C}\right]$ citrate in vitro. The results of the previous experiments might be due to alterations in the concentration of serum chloride bathing the kidney. It has been shown that urinary citrate excretion is dependent on the ability of renal tubules to reabsorb filtered citrate (12), and this resorptive capacity is probably a function of the renal tubular cells ability to oxidize citrate accumulated intracellularly $(4,13)$. Measurement of citrate decarboxylation by renal cortical tissue at different external chloride concentrations should, therefore, partially describe chloride's effect upon renal citrate metabolism. Renal cortical slices were obtained from potassium chloride-deficient rats whose extracellular acid-base status and serum and tissue potassium concentrations were statistically identical to those of the potassium-depleted rats shown in Table $\mathrm{I}$. The slices were incubated in low (70 meq) and "normal" (110 meq) chloride solutions and ${ }^{14} \mathrm{CO}_{2}$ production was measured. The results are shown in Fig. 3. As ${ }^{14} \mathrm{CO}_{2}$ production is equal in the two groups it appears that chloride concentration does not directly affect renal citrate metabolism. To further examine the effect of chloride concentration on renal metabolism and to determine whether changes in extracellular volume might account for the observed results additional experiments were performed.

Expansion of intravascular volume by mannitol in potassium-depleted rats: effect on renal citrate and ammonia metabolism. Mannitol infusions were given to potassium chloride-depleted animals. The effect of this infusion was to expand intravascular volume and lower serum chloride concentration. Another group of animals was given low volume dextrose infusion over a similar time period to serve as a control. Serum and tissue potassium concentrations in the animals before and after infusion were similar to that of the animals shown in Table I. Muscle potassium concentration after infusion in the dextrose and mannitol groups was 304 \pm 30 and $312 \pm 36 \mathrm{meq} / \mathrm{kg}$ of dry weight, respectively, compared to a muscle potassium concentration in nonpotassium chloride-depleted animals of $465 \mathrm{meq} / \mathrm{kg}$ dry weight $(P<0.001)$. Renal potassium content in the dextrose and mannitol rats was $267 \pm 26$ and $252 \pm 32$

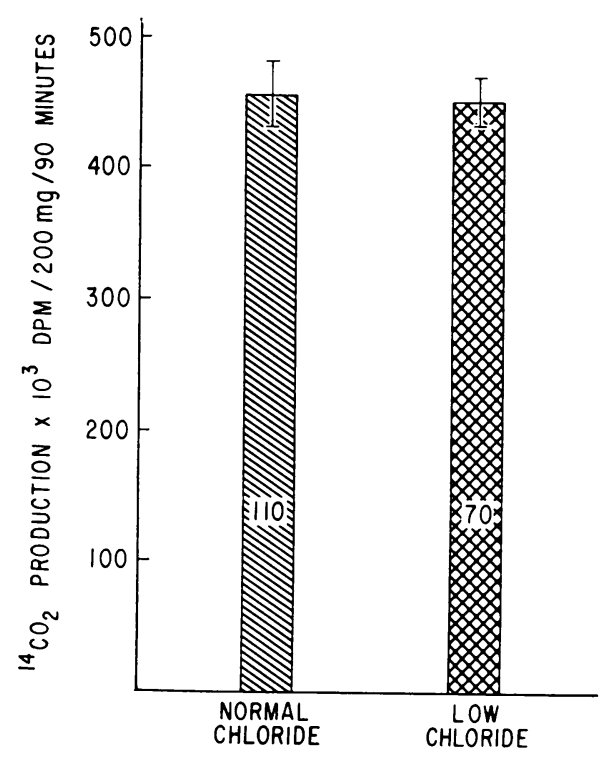

FIGURE 3 The effect of medium chloride concentration on citrate decarboxylation by renal cortical slices. The numbers within the bars represent medium chloride concentrations in each group while the brackets depict $\pm 1 \mathrm{SE}$ of the mean. 
TABLE IV

Creatinine Clearance, Urinary $p H$, and Renal Citrate Content in KCL-Depleted Rats Infused with either Dextrose or Mannitol Solutions*

\begin{tabular}{|c|c|c|c|}
\hline & $\mathrm{C}_{\text {er }}$ & $\begin{array}{l}\text { Urinary } \\
\mathrm{pH}\end{array}$ & $\begin{array}{r}\text { Renal cortical } \\
\text { citrate content }\end{array}$ \\
\hline & $m l / m i n$ & & $\begin{array}{l}\mu \mathrm{mol} / \mathrm{g} \\
\text { wet weight }\end{array}$ \\
\hline $\begin{array}{l}\text { Dextrose infused, } n=12 \\
\text { Mannitol infused, } n=13\end{array}$ & $1.35 \pm 0.29$ & $6.83 \pm 0.12$ & $0.075 \pm 0.008$ \\
\hline Control & $1.40 \pm 0.19$ & $6.88 \pm 0.14$ & \\
\hline Experiment 1 & $2.02 \pm 0.16 \mp \delta$ & $7.06 \pm 0.05$ & $0.049 \ddagger \pm 0.005$ \\
\hline Experiment 2 & $1.68 \pm 0.18$ & $7.10 \pm 0.05$ & \\
\hline Experiment 3 & $1.84 \pm 0.20 \neq \S$ & $7.08 \pm 0.05$ & \\
\hline
\end{tabular}

* Each value represents the mean $\pm \mathrm{SEM}$.

‡ Statistically significant differences from dextrose-infused animals $(P<0.05)$.

\& Statistically significant differences from control values in mannitolinfused rats $(P<0.05)$.

$\mathrm{meq} / \mathrm{kg}$ dry weight, respectively, compared to $312 \pm 18$ $\mathrm{meq} / \mathrm{kg}$ of dry weight in nondepleted control animals. Muscle and renal potassium content did not significantly differ between dextrose and mannitol-infused rats $(P>0.4)$.

The effect of the dextrose and mannitol infusions on extracellular conditions in potassium chloride-depleted rats is shown in Table III. Arterial $\mathrm{pH}$ before and after infusion was unchanged in either group. Mannitol infusion had no effect on the serum potassium level but did lower extracellular bicarbonate concentration significantly $(P<0.01)$. Neither serum creatinine nor blood citrate levels were significantly affected by mannitol infusion. The result of acute mannitol infusions

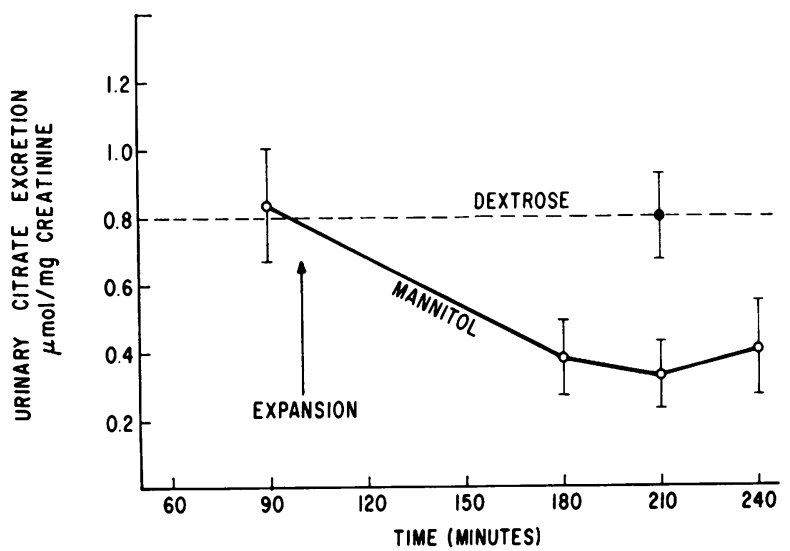

Figure 4 The effect of mannitol-induced volume expansion on urinary citrate excretion. The closed circle is the value obtained after $210 \mathrm{~min}$ of dextrose infusion while the opened circles are values obtained in the mannitol-infused rats. The dashed horizontal line represents the value for the dextrose-infused group. The brackets depict $\pm 1 \mathrm{SE}$ of the mean.

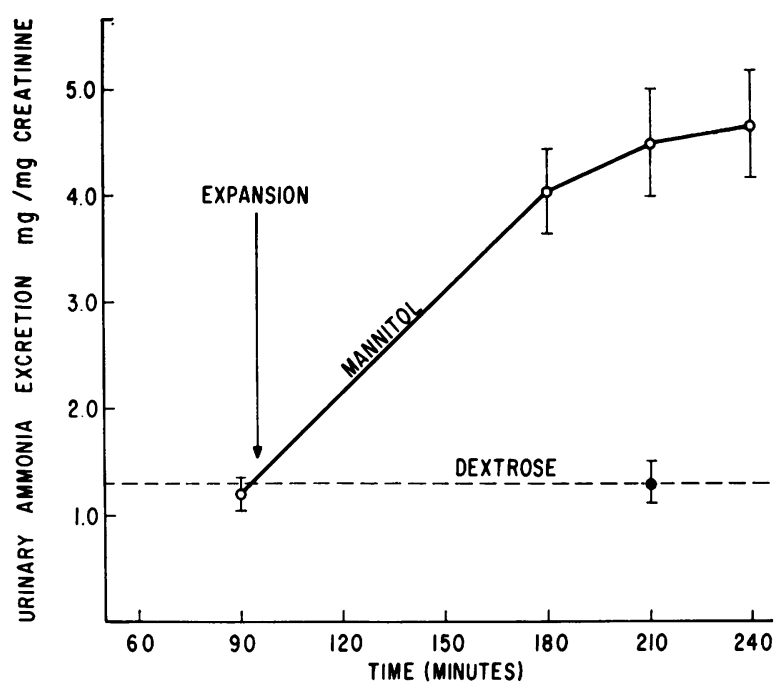

Figure 5 The effect of mannitol-induced volume expansion on urinary ammonia excretion. Conventions in this figure are the same as for Fig. 4.

on extracellular conditions, therefore, was similar to that previously shown in the rats chronically given sodium chloride. Serum bicarbonate concentration and arterial $\mathrm{PCo}_{2}$ fell, metabolic alkalosis was maintained, and blood citrate levels were unaffected. A significant difference is that mannitol infusion decreased the serum chloride concentration while sodium chloride administration raised serum chloride concentration to normal levels.

As was seen with sodium chloride ingestion, mannitol infusion lowered urinary citrate excretion. This is shown in Fig. 4. Citrate excretion in each of the experimental periods is significantly reduced compared to control period values or to excretion in the dextroseinfused animals $(P<0.01)$. Fig. 5 shows the effect on ammonia excretion. In this case, however, urinary ammonia was significantly elevated in each of the mannitol experimental periods compared to control period values or to results obtained in dextrose-infused animals $(P<0.001)$. Citrate and ammonia excretions during the control period were similar in the two groups $(P>0.5)$. The alteration in citrate excretion after mannitol infusion is probably secondary to changes in the filtered load of citrate as experiments employing radioactive labeled citrate indicate that the citrate in the urine comes from extrarenal citrate (13). Thus, urinary citrate essentially represents the net sum of filtered citrate less reabsorbed citrate (14). Table IV, however, shows that changes in filtered load do not account for the observed decrease in urinary citrate excretion. Glomerular filtration rate, calculated from the endogenous creatinine clearance, was increased during mannitol infusion compared both to control period 
TABLE $\mathrm{V}$

Skeletal Muscle, Cardiac, and Liver Cell pH in KCl-Depleted_Rats Infused with either Dextrose or Mannitol Solutions*

\begin{tabular}{|c|c|c|c|c|c|c|}
\hline & \multicolumn{2}{|c|}{ Skeletal muscle } & \multicolumn{2}{|c|}{ Cardiac muscle } & \multicolumn{2}{|c|}{ Liver } \\
\hline & $\mathbf{K}$ & pHрuо & $\mathbf{K}$ & pHpхo & $\mathbf{K}$ & pHDwo \\
\hline & \multicolumn{2}{|c|}{ meq/kg dry weight } & \multicolumn{2}{|c|}{ meq/kg dry weight } & \multicolumn{2}{|c|}{ meq/kg dry weight } \\
\hline Dextrose infused, $n=12$ & $\begin{array}{r}304 \\
\pm 9\end{array}$ & $\begin{array}{r}6.88 \\
\pm 0.03\end{array}$ & $\begin{array}{r}273 \\
\pm 8\end{array}$ & $\begin{array}{r}7.10 \\
\pm 0.03\end{array}$ & $\begin{array}{l}336 \\
\pm 8\end{array}$ & $\begin{array}{r}7.14 \\
\pm 0.03\end{array}$ \\
\hline Mannitol infused, $n=13$ & $\begin{array}{r}312 \\
\pm 11\end{array}$ & $\begin{array}{r}6.93 \\
\pm 0.03\end{array}$ & $\begin{array}{l}282 \\
\pm 9\end{array}$ & $\begin{array}{r}7.15 \\
\pm 0.02\end{array}$ & $\begin{array}{c}282 \ddagger \\
\pm 8\end{array}$ & $\begin{array}{r}7.14 \\
\pm 0.02\end{array}$ \\
\hline
\end{tabular}

* Values represent the mean $\pm \mathrm{SE}$ of the mean.

$\ddagger$ Differs significantly from dextrose-infused animals $(P<0.01)$.

values and to the filtration rate of the dextrose-infused animals. This increase was statistically significant only in periods two and four $(P<0.05)$. This change in filtration rate combined with the slight increase in blood citrate (Table III) shows that filtered citrate increased rather than decreased during mannitol infusion. Thus, decreased urinary citrate excretion is probably due to increased tubular reabsorption of filtered citrate. Further proof that the alterations in urinary citrate excretion reflect altered renal citrate metabolism is given in Table IV. The data show that renal cortical citrate content in the mannitol-infused rats was significantly reduced compared to that found in the control rats $(P<0.001)$. Increased urinary ammonia excretion similarly appears to be secondary to changes in renal metabolism rather than to a nonspecific effect of the mannitol infusion. Urinary ammonia excretion ordinarily rises when urinary $\mathrm{pH}$ falls (15). The data presented in Table IV show that urinary $\mathrm{pH}$ rose rather than fell during mannitol infusion. The rise was not significant, however, compared to control period values or to values obtained in the dextrose-infused rats $(P<0.1)$. Thus, chronic $\mathrm{NaCl}$ ingestion and acute mannitol infusion in $\mathrm{KCl}$ depleted rats reduce renal cortical citrate content, lower urinary citrate excretion, and increase urinary ammonia excretion.

Effect of mannitol-induced volume expansion on muscle, liver, and cardiac $p H$. Although renal tubular cell $\mathrm{pH}$ cannot be directly determined in vivo, skeletal muscle, liver, and cardiac muscle cell $\mathrm{pH}$ may be calculated from distribution of the weak acid 5,5-dimethyl2,-4-oxazolidinedione (DMO) (16). Table V shows the effect of mannitol infusion on the intracellular $\mathrm{pH}$ of these three tissues. Extracellular potassium concentration was approximately $2.5 \mathrm{meq} /$ liter (Table III) in these animals. The concentration of potassium in each of the three tissues (Table V) demonstrates that a higher intracellular to extracellular gradient existed at the conclusion of the infusion in each of the tissues studied. Membrane selectivity was thus maintained and the DMO distribution method for measuring cell $\mathrm{pH}$ may be employed (16). It is apparent that mannitol infusion did not lower intracellular $\mathrm{pH}$ in any of the three tissues. Indeed, there was a tendency in skeletal and cardiac muscle for intracellular $\mathrm{pH}$ to increase. This increase was not statistically significant $(P>$ 0.05). As shown in Table III, the slight elevation of cell $\mathrm{pH}$ cannot be due to a change in extracellular $\mathrm{pH}$ for final arterial blood $\mathrm{pH}$ in the mannitol-infused rats was slightly lower than the final blood $\mathrm{pH}$ of the dextrose-infused animals. The rise in cell $\mathrm{pH}$ might be explained by the decreased $\mathrm{CO}_{2}$ tension in the mannitol-infused rats since carbon dioxide readily penetrates cell membranes and might influence cell $\mathrm{pH}$ more than bicarbonate (17). Citrate content was determined in liver and gluteal muscle tissue. No differences were found between dextrose and mannitol-infused animals. This is consistent with the absence of significant intracellular $\mathrm{pH}$ differences since tissue citrate content apparently is a function of intracellular $\mathrm{pH}$ (5).

\section{DISCUSSION}

These experiments extend previous work which demonstrated that administration of sodium chloride to potassium chloride-deficient rats alters renal citrate metabolism (1). Whether sodium chloride altered renal citrate metabolism by changing extracellular chloride concentration or extracellular volume was not, however, examined in the earlier study. The present results show that the alteration in renal citrate metabolism is not due to changes in serum chloride concentration since volume expansion with mannitol had the same effect as sodium chloride on extracellular acid base status and renal citrate metabolism despite having an opposite effect on serum chloride concentration. Rather, it appears that increased circulating volume is responsible 
for the altered renal metabolism. Although circulating volume was not measured in the tube fed rats, weight loss in the $\mathrm{NaCl}$-repleted animals over the 3 days of feeding was $10 \mathrm{~g}$ less than in $\mathrm{K}$-depleted or $\mathrm{KHCO}_{s}$ rats. There was sufficient scatter in the data to make this difference nonsignificant $(P>0.05,<0.1)$. Most studies, however, show only small increases or decreases in extracellular volume after chloride repletion or depletion (18), so the inability to obtain significant data under the conditions of the present experiments is not surprising. In addition, expansion of extracellular volume in rats decreases renal bicarbonate reabsorptive capacity (19). Thus, the increase in urinary $\mathrm{pH}$ during mannitol infusion and the fall in serum bicarbonate after $\mathrm{NaCl}$ mannitol administration is consistent with an increased circulating volume.

In addition to its effect on renal citrate metabolism volume expansion increased ammonia excretion. The latter probably reflects increased renal ammonia production for two reasons. First, the increase was accompanied by a simultaneous rise in urine $\mathrm{pH}$ in the mannitol-infused rats. $\mathrm{P}_{\mathrm{NH}_{3}}$ is in equilibrium between peritubular and luminal fluid (20), so the concentration of total urinary ammonia $\left(\mathrm{NH}_{3}\right.$ plus $\left.\mathrm{NH}_{4}^{+}\right)$varies directly with the $\mathrm{pH}$ gradient between peritubular and luminal fluid; the greater the gradient the higher the urinary ammonia excretion. As blood $\mathrm{pH}$ was constant the gradient must have fallen. Less of the relatively nondiffusable $\mathrm{NH}_{4}{ }^{+}$is then trapped in the tubular lumen, and urinary ammonia excretion should fall if renal ammonia production is constant $(15,21)$. Elevated urinary ammonia in these circumstances indicates increased renal ammonia production. This mechanism probably explains the decreased ammonia excretion seen in the rats given potassium bicarbonate. A second reason why increased production is probably responsible for the increased ammonia excretion is that renal blood flow and glomerular filtration rate ordinarily rise after volume expansion (22). Endogenous creatinine clearance increased in the rats infused with mannitol so renal blood flow probably also increased. As peritubular blood traps ammonia increased renal blood flow should increase ammonia transport into renal venous blood and decrease the amount of ammonia available for urinary excretion especially when the urine is only weakly acid and urine flow rate is high. Increased renal blood flow plus a rise in urinary $\mathrm{pH}$ indicate that elevated urinary ammonia excretion after $\mathrm{NaCl}$ or mannitol administration is due, therefore, to increased renal ammonia production.

The volume expansion-induced alterations in renal citrate and ammonia metabolism cannot, obviously, be explained by changes in chloride concentration or by a nonspecific effect of mannitol. Three possibilities, not mutually exclusive, may explain the results: the renal metabolic changes could be due to the observed isohydric reduction in extracellular bicarbonate; they could be secondary to a decrease in renal tubular cell potassium concentration; or the changes could represent a response to a reduction in renal tubular cell $\mathrm{pH}$. Supporting the first possibility are the many studies showing that varying extracellular bicarbonate concentration at a constant extracellular $\mathrm{pH}$ alters intermediary metabolism in a variety of tissues $(23,24)$. Indeed, Kamm, Fruisz, Goodman, and Cahill (25) have shown that gluconeogenesis in rat renal cortical slices varies inversely with the bicarbonate concentration of the medium at a constant extracellular $\mathrm{pH}$ of 7.40 . Since ammonia and glucose production by rat renal cortical slices obtained from metabolically acidotic animals is greater than that seen in slices obtained from alkalotic animals (26), it is possible the increased ammonia production in rats given $\mathrm{NaCl}$ or mannitol is due to the decreased bicarbonate concentration. Citrate metabolism also appears to be bicarbonate dependent. Adler (27) has demonstrated that the citrate content of rat diaphragm muscle is decreased in an iso- $\mathrm{pH}$ system when bicarbonate concentration is lowered. Furthermore, Simpson (4) has shown that under isohydric conditions in vitro citrate decarboxylation by renal mitochondria proceeds more rapidly as bicarbonate concentration is progressively lowered. This apparently is due to increased transport of citrate into the mitochondria (28). Increased citrate decarboxylation intramitochondrially would decrease renal citrate content and increase reabsorption of citrate, the results observed in the present study. Other work of Simpson (4), however, is not in accord with his observations in isolated mitochondria. Rabbit renal cortical slices incubated at a constant external $\mathrm{pH}$ of 7.39 and at bicarbonate concentrations varying from 10 to $50 \mathrm{meq} /$ liter showed identical citrate decarboxylation rates. These slices, however, were quite responsive to alterations in external $\mathrm{pH}$ as the citrate decarboxylation rate varied inversely with the $\mathrm{pH}$ of the bathing medium. If the whole kidney responds like the slice then a change in bicarbonate concentration occurring isohydrically would not be expected to alter renal citrate metabolism. The exact role of the decreased bicarbonate concentration, therefore, remains unclear.

A second possibility is that the altered renal metabolism is a consequence of altered intracellular potassium concentration. When normal animals are made alkalotic, urinary citrate excretion (29) and renal citrate content (2) increase while renal ammonia production and excretion decrease (30). In potassium deficiency, however, urinary citrate excretion falls (12), and urinary ammonia excretion rises (30) despite the presence 
of an extracellular alkalosis. This has been attributed to coexisting intracellular acidosis and extracellular alkalosis in potassium depletion. Because the changes in $\mathrm{pH}$ are accompanied by a fall in tissue potassium concentration, some investigators believe that the renal metabolic alterations are due to decreased intracellular potassium concentration rather than renal intracellular acidosis. In the present experiment, however, renal potassium content did not decrease further after sodium chloride ingestion or mannitol infusion. In addition, Adler, Anderson, and Zett (5) have shown that the citrate content of potassium-depleted rat diaphragm muscle in vitro is a function of cell $\mathrm{pH}$ (calculated from DMO distribution) and not the tissue potassium content. Thus, a fall in diaphragm muscle cell $\mathrm{pH}$ is accompanied by a decrease in tissue citrate content without any change in cellular potassium. It seems unlikely, therefore, that changes in intrarenal potassium concentration account for the renal metabolic alterations although changes in potassium concentration within specific areas of the cell cannot be ruled out.

Finally, the alterations in renal citrate and ammonia metabolism may reflect reduced renal tubular cell $\mathrm{pH}$. Acidosis apparently increases renal decarboxylation of exogenous citrate leading to a decrease in urinary citrate excretion and renal citrate content while the converse occurs in alkalosis (4). The observed changes in renal citrate content and excretion thus are compatible with renal cell acidosis. Indeed, Crawford, Milne, and Scribner (12), as well as other investigators (28), have postulated that renal citrate metabolism reflects intracellular $\mathrm{pH}$, using as supporting evidence for this hypothesis the decreased citrate excretion and renal cortical citrate content found in potassium deficiency alkalosis (12) and the known decrease in muscle cell $\mathrm{pH}$ which occurs simultaneously $(31,32)$. In muscle there is direct evidence supporting the concept that citrate metabolism is a function of cell $\mathrm{pH}$ not of extracellular acidity. Rats acutely administered potassium chloride intraperitoneally develop extracellular metabolic acidosis, intracellular metabolic alkalosis, and elevated skeletal muscle citrate content (33). Ordinarily, tissue citrate decreases in acidosis (2), so the ichange in citrate content presumably reflects the intracellular not the extracellular $\mathrm{pH}$ state. Also, as mentioned previously, Adler and coworkers (5) have been able to relate citrate metabolism in diaphragm muscle to intracellular $\mathrm{pH}$, not to cell potassium content or extracellular $\mathrm{pH}$. Renal ammonia production is also felt to reflect intracellular rather than extracellular $\mathrm{pH}$ conditions. As is the case with renal citrate metabolism this hypothesis is based on indirect evidence obtained in abnormal metabolic states since renal cell $\mathrm{pH}$ has only been determined in an isolated renal tubular cell preparation (34). Most investigators agree, nevertheless, that both hydrogen ion secretion and renal ammonia production are regulated by intracellular $\mathrm{pH}$. Both, for example, are increased in potassium deficiency despite a concomitant metabolic alkalosis (35). Also glutamine oxidation and presumably ammonia production in renal cortical slices and mitochondria is directly related to changes in $\mathrm{pH}$ (36). Finally, Lowance, Garfinkel, Mattern, and Schwartz (37) demonstrated that hypotonic volume expansion in dogs with chronic metabolic acidosis increases net acid excretion and restores plasma bicarbonate concentration to normal. The increased net acid excretion probably was due in part to an increase in ammonia excretion. Although it is unclear how volume expansion might decrease renal cell $\mathrm{pH}$, the data are consistent with the hypothesis that volume expansion lowers renal tubular cell $\mathrm{pH}$.

\section{ACKNOWLEDGMENTS}

The authors wish to thank Mrs. Elaine R. New for her assistance in manuscript preparation.

This work was supported in part by United States Public Health Service Grant HL 13810-04.

\section{REFERENCES}

1. Adler, S., B. Zett, and B. Anderson. 1974. Renal citrate in the potassium-deficient rat: role of potassium and chloride ions. J. Lab. Clin. Med. 84: 307-316.

2. Adler, S., B. Anderson, and L. Zemotel. 1971. Metabolic acid-base effects on tissue citrate content and metabolism in the rat. Am. J. Physiol. 220: 986-992.

3. Ostberg, O. 1931. Studien uber die Zitronen saureausscherdung der Menschennisre in normalen and patholgischen Zustanden. Skand. Arch. Physiol. 62: 81-222.

4. Simpson, D. P. 1967. Regulation of renal citrate metabolism by bicarbonate ion and $\mathrm{pH}$. Observations in tissue slices and mitochondria. J. Clin. Invest. 46: 225-238.

5. Adler, S., B. Anderson, and B. Zett. 1974. Regulation of citrate metabolism by cell $\mathrm{pH}$ in potassium-depleted rat diaphragm. Kidney Int. 6: 92-98.

6. Waddell, W. J., and R. G. Bates. 1969. Intracellular pH. Physiol. Rev. 49: 285-329.

7. Adler, S., A. Roy, and A. S. Relman. 1965. Intracellular acid-base regulation. I. The response of muscle cells to changes in $\mathrm{CO}_{2}$ tension or extracellular bicarbonate concentration. J. Clin. Invest. 44: 8-20.

8. Moellering, H., and W. Gruber. 1966. Determination of citrate with citrate lyase. Anal. Biochem. 17: 369-376.

9. Conway, E. J., and E. O'Malley. 1942. Microdiffusion methods. Ammonia and urea lising buffered absorbants. Biochem. J. 36: 655-661.

10. Schloerb, P. R., and J. J. Grantham. 1965. Intracellular $\mathrm{pH}$ measurement with tritiated water, carbon-14 labeled 5,5-dimethyl-2,4-oxazolidinedione, and chloride-36. J. Lab. Clin. Med. 65: 669-676.

11. Luke, R. G., and H. Levitin. 1967. Impaired renal conservation of chloride and the acid-base changes associated with potassium depletion in the rat. Clin. Sci. (Oxf.). 32: 511-526.

12. Crawford, M. A., M. D. Milne, and B. H. Scribner. 1959. The effects of changes in acid-base balance on

Expansion, Renal Citrate, and Ammonia Metabolism in KCl Deficiency 
urinary citrate in the rat. J. Physiol. (Lond.). 149: 413-423.

13. Gordon, E. E. 1961. The metabolism of citrate- ${ }^{14} \mathrm{C}$ in normal and in fluoro inhibitor-poisoned rats. J. Clin. Invest. 40: 1719-1726.

14. Grollman, A. P., H. C. Harrison, and H. E. Harrison. 1961. The renal excretion of citrate. J. Clin. Invest. 40: 1290-1296.

15. Orloff, J., and R. W. Berliner. 1956. The mechanism of the excretion of ammonia in the dog. J. Clin. Invest. $35: 223-235$.

16. Waddell, W. J., and T. C. Butler. 1959. Calculation of intracellular $\mathrm{pH}$ from the distribution of 5,5-dimethyl2,4-oxazolidinedione (DMO). Application to skeletal muscle of the dog. J. Clin. Invest. 38: 720-729.

17. Adler, S., A. Roy, and A. S. Relman. 1965. Intracellular acid-base regulation. II. The interaction between $\mathrm{CO}_{2}$ tension and extracellular bicarbonate in the determination of muscle cell $\mathrm{pH}$. J. Clin. Invest. 44: 21-30.

18. Atkins, E. L., and W. B. Schwartz. 1962. Factors governing correction of the alkalosis associated with potassium deficiency; the critical role of chloride in the recovery process. J. Clin. Invest. 41: 218-229.

19. Purkerson, M. L., H. Lubowitz, R. W. White, and N. S. Bricker. 1969. On the influence of extracellular fluid volume expansion on bicarbonate reabsorption in the rat. J. Clin. Invest. 48: 1754-1760.

20. Denis, G., H. Preuss, and R. Pitts. 1964. The $P_{\mathrm{NH}_{3}}$ of renal tubular cells. J. Clin. Invest. 43: 571-582.

21. Milne, M. D., B. H. Schribner, and M. A, Crawford. 1958, Nonionic diffusion and the excretion of weak acids and bases. Am. J. Med. 24: 709-729.

22. Earley, L. E., and R. M. Friedler. 1965. Changes in renal blood flow and possibly the intrarenal distribution of blood during natriuresis accompanying saline loading in the dog. J. Clin. Invest. 44: 929-941.

23. Katzman, R., C. A. Villee, and H. K. Beecher. 1953. Effect of increased carbon dioxide concentrations on fixed acid production in vitro. Am. J. Physiol. 172: 317-323.

24. Longmore, W. J., A. B. Hastings, and T. A. Mahowald. 1964. Effect of environmental $\mathrm{CO}_{2}$ and $\mathrm{pH}$ on glycerol metabolism by rat liver in vitro. J. Biol. Chem. 239: 1700-1704.

25. Kamm, D. E., R. E. Fuisz, A. D. Goodman, and G. F. Cahill, Jr. 1967. Acid-base alterations and renal gluco- neogenesis : effect of $\mathrm{pH}$, bicarbonate concentration, and Pcos. J. Clin. Invest. 46: 1172-1177.

26. Goodman, A. D., R. E. Fuisz, and G. F. Cahill, Jr. 1966. Renal gluconeogenesis in acidosis, alkalosis, and potassium deficiency: its possible role in regulation of renal ammonia production J. Clin. Invest. 45: 612-619.

27. Adler, S. 1970. The role of $\mathrm{pH}, \mathrm{PCO}_{2}$ and bicarbonate in regulating rat diaphragm citrate content. J. Clin. Invest. 49 : 1647-1655.

28. Simpson, D. P., and S. Angielski. 1973. Regulation by bicarbonate ion of intramitochondrial citrate concentration in kidney mitochondria. Biochim. Biophys. Acta. 298: $115-123$.

29. Simpson, D. P. 1964. Influence of plasma bicarbonate concentration and $\mathrm{pH}$ on citrate excretion. Am. J. Physiol. 206: 875-882.

30. Balagura-Baruch, S. 1971. Renal metabolism and transfer of ammonia. In The Kidney. C. Rouiller and A. F. Muller, editors. Academic Press, Inc, New York. 3: 253-327.

31. Cooke, R. E., W. E. Segar, D. B. Cheek, F. E. Colville, and D. C. Darrow. 1952. The extrarenal correction of alkalosis associated with potassium deficiency. J. Clin. Invest. 31: 798-805.

32. Adler, S., B. Zett, and B. Anderson. 1972. The effect of acute potassium depletion on muscle cell $\mathrm{pH}$ in vitro. Kidney Int. 2 : 159-163.

33. Hudson, J. B., and A. S. Relman. 1962. Effects of potassium and rubidium on muscle cell bicarbonate. Am. J. Physiol. 203: 209-214.

34. Struyvenberg, A., R. B. Morrison, and A. S. Relman. 1968. Acid-base behaviour of separated canine renal tubular cells. Am. J. Physiol. 214: 1155-1162.

35. Huth, E. J., R. D. Squires, and J. R. Elkinton. 1959. Experimental potassium depletion in normal human subjects. II. Renal and hormonal factors in the development of extracellular alkalosis during depletion. J. Clin. Invest. 38: 1149-1165.

36. Simpson, D. P., and J. D. Sherrard. 1969. Regulation of glutamine metabolism in vitro by bicarbonate ion and pH. J. Clin. Invest. 48: 1088-1096.

37. Lowance, D. C., H. B. Garfinkel, W. D. Mattern, and W. B. Schwartz. 1972. The effect of chronic hypotonic volume expansion on the renal regulation of acid-base equilibrium. J. Clin. Invest. 51 : 2928-2940. 